\title{
Measuring the Intangible Aspects of the Manufacturing Strategy - A Case Study from the Automotive Industry
}

\author{
Bjørnar Henriksen ${ }^{1}$ and Lars E. Onsøyen ${ }^{2}$ \\ ${ }^{1}$ Norwegian University of Science and Technology, 7491 Trondheim, Norway \\ ${ }^{2}$ SINTEF Technology and Society, 7465 Trondheim, Norway
}

\begin{abstract}
In this paper we focus on how manufacturing strategies should be measured in an increasingly complex manufacturing environment where the "traditional" quality and productivity measures are not sufficient. The paper discusses and illustrates measures, quantitative and qualitative, that are relevant for manufacturing strategies based on principles from different paradigms. From our case in the automotive industry we see that the company should measure intangible aspects, but that they could be difficult to measure and there is a risk of just measuring what could be counted. There could easily be a discrepancy between what are actually measured and what should have been measured according to the announced strategy.
\end{abstract}

Keywords: Performance management, manufacturing strategy, automotive industry.

\section{Introduction}

The network- and knowledge-based economy is triggering continuous changes in the way companies are organized and the way they do business [1]. This has given us more complex challenges when making strategies, implementing them into operations, and measuring them. We need more information, of a better quality and on other aspects than before. Answering the two basic questions in performance measurement, what- and how to measure, are more and more difficult.

The primary function of a manufacturing strategy is to guide the business in putting together the manufacturing capabilities enabling it to pursue its chosen competitive strategy of the long term [2]. Thus, manufacturing strategy should not only cover quantifiable aspects such as how much-, how- and where- to produce. Stakeholder relations, knowledge and innovativeness, and organizational culture are examples of intangible aspects that are increasingly important in manufacturing strategies.

Performance measurement is normally focusing on quantifications and numbers, with the intention to provide us with an objective, uniform and often complete picture of reality. However, some aspects are not easily quantified, inherently and difficult to 
measure. These less tangible aspects are often capabilities that increasingly drive our future performance. Some way they have to be assessed and managed. Marr describes three challenges in strategic performance management:

- an incomplete picture of the strategy,

- the wrong performance measures,

- the wrong approach towards managing performance [3, p.1]

In this paper we focus on the second point and discuss how manufacturing strategies should be measured. Our reference for this discussion is manufacturing paradigms and especially how lean manufacturing emphasizes intangible aspects requiring a different way of measuring performance than for example in mass manufacturing. Measuring according to lean strategies is not evident. This is illustrated through a case from a supplier in the automotive industry. The case is based on documents and system descriptions, and in depths interviews with 12 engineers and managers throughout 2008.

The composition of the paper is as follows: First we give a brief introduction to the fields of manufacturing strategy and performance measurement. Chapter 3 is a presentation of the case, which represents a reference for the discussion in chapter 4 of how to measure the manufacturing strategy.

\section{How to Measure Manufacturing Strategy}

\subsection{Manufacturing Strategy}

Even though new management concepts often have been abandoned before they are allowed to fully prove their relevance we have seen that each new concept has brought new elements to the table [5]. These elements put into a more coherent and holistic context could be regarded as paradigms [6]. In Table 1 Henriksen and Rolstadås [7] illustrate how paradigms could be identified based on a set of criteria. Paradigms represent principles, methods etc that inspire companies and are reflected in manufacturing strategies.

Hill [8] presents basic principles for the manufacturing strategies based on the more recent paradigms:

- a discretionary approach to change to ensure that scarce development resources are used in those areas that will yield best returns;

- as with process choice, it is necessary to establish and then choose between sets and trade-offs that go hand in hand with each decision;

- the infrastructure design must respond to dynamics of reality and much of necessary change can be achieved incrementally;

- continuous development is easier to bring about where the responsibility for identifying and implementing improvements is locally based 
Table 1. Manufacturing paradigms [7]

\begin{tabular}{|c|c|c|c|c|c|}
\hline \multicolumn{2}{|c|}{ Aspects } & \multicolumn{3}{|c|}{ Paradigm } & \multirow[b]{2}{*}{$\begin{array}{c}\text { Adaptive } \\
\text { manufacturi } \\
\text { ng }\end{array}$} \\
\hline Field & Criteria & $\begin{array}{c}\text { Craft } \\
\text { manufacturing }\end{array}$ & $\begin{array}{c}\text { Mass } \\
\text { manufacturing }\end{array}$ & $\begin{array}{c}\text { Lean } \\
\text { manufacturing }\end{array}$ & \\
\hline \multirow{3}{*}{$\begin{array}{l}\text { Business } \\
\text { model }\end{array}$} & Started & $1850 \mathrm{~s}$ & $1910 \mathrm{~s}$ & $1980 \mathrm{~s}$ & $2000 s$ \\
\hline & $\begin{array}{l}\text { Customer } \\
\text { requirements }\end{array}$ & $\begin{array}{l}\text { Customized } \\
\text { products }\end{array}$ & $\begin{array}{l}\text { Low cost } \\
\text { products }\end{array}$ & Variety of products & $\begin{array}{c}\text { Mass } \\
\text { customized } \\
\text { products }\end{array}$ \\
\hline & Market & $\begin{array}{c}\text { Pull. } \\
\text { Very small } \\
\text { volume per } \\
\text { product }\end{array}$ & $\begin{array}{c}\text { Push } \\
\text { Demand }>\text { Supply } \\
\text { Steady demand }\end{array}$ & $\begin{array}{c}\text { Push-Pull } \\
\text { Supply }>\text { Demand } \\
\text { Smaller volume per } \\
\text { product }\end{array}$ & $\begin{array}{c}\text { Pull } \\
\text { Globalization, } \\
\text { segmentation } \\
\text { Fluctiating } \\
\text { demand } \\
\end{array}$ \\
\hline \multirow[t]{2}{*}{ Innovations } & $\begin{array}{l}\text { Process - } \\
\text { enabler }\end{array}$ & $\begin{array}{c}\text { Electricity } \\
\text { Machine tools }\end{array}$ & $\begin{array}{c}\text { Moving } \\
\text { assembly line } \\
\text { and DML }\end{array}$ & $\begin{array}{c}\text { FMS Robots } \\
\text { Modulized products }\end{array}$ & $\begin{array}{c}\text { RMS } \\
\text { Information } \\
\text { technology }\end{array}$ \\
\hline & $\begin{array}{l}\text { Innovation } \\
\text { process }\end{array}$ & Incremental & $\begin{array}{l}\text { Linear and } \\
\text { radical }\end{array}$ & $\begin{array}{l}\text { Incremental and } \\
\text { linear }\end{array}$ & $\begin{array}{l}\text { Incremental } \\
\text { and radical }\end{array}$ \\
\hline \multirow[t]{4}{*}{ Knowledge } & Behaviour & $\begin{array}{c}\text { Practical oriented } \\
\text { (skills } \\
\text { Learning by } \\
\text { doing) }\end{array}$ & $\begin{array}{c}\text { Centralized } \\
\text { decisionmaking. } \\
\text { Learning by } \\
\text { instructions }\end{array}$ & $\begin{array}{c}\text { Decentralized } \\
\text { decisionmaking. } \\
\text { Continuous } \\
\text { improvement } \\
\text { Learning by doing }\end{array}$ & $\begin{array}{c}\text { Decentralized } \\
\text { decisionmaking } \\
\text {.Knowledge to } \\
\text { be applied } \\
\text { instantly } \\
\end{array}$ \\
\hline & $\begin{array}{l}\text { Knowledge } \\
\text { creation }\end{array}$ & Tacit knowledge & $\begin{array}{c}\text { Explicit } \\
\text { knowledge }\end{array}$ & Tacit knowledge & $\begin{array}{l}\text { Tacit and } \\
\text { explicit } \\
\text { knowledge }\end{array}$ \\
\hline & $\begin{array}{l}\text { Knowledge } \\
\text { base }\end{array}$ & Synthetic & Analytical & $\begin{array}{c}\text { Analytical and } \\
\text { Synthetic }\end{array}$ & $\begin{array}{c}\text { Analytical and } \\
\text { synthetic }\end{array}$ \\
\hline & $\begin{array}{l}\text { Knowledge } \\
\text { transfer- } \\
\text { challenge }\end{array}$ & $\begin{array}{c}\text { Externalize } \\
\text { knowledge } \\
\text { communicating } \\
\text { with customers } \\
\end{array}$ & $\begin{array}{l}\text { Internalize } \\
\text { knowledge, for } \\
\text { practical use }\end{array}$ & $\begin{array}{c}\text { Externalize } \\
\text { knowledge, making it } \\
\text { more explicit }\end{array}$ & $\begin{array}{c}\text { Continuously } \\
\text { externalize and } \\
\text { internalize } \\
\text { knowledge } \\
\end{array}$ \\
\hline
\end{tabular}

\subsection{Performance Measurement - Tangible and Intangible Measures}

Marr [3] presents three basic and overlapping reasons for measuring performance: reporting and compliance; controlling people's behaviour; and strategic decision making and learning, which has traditionally been based on three principles [9]:

1. performance should be clearly defined,

2. accurately measured and

3. reward should be contingent on measured performance

These principles are still relevant for some purposes and types of measurement but clearly imply risks such as; just measuring what could be counted, data overload or just rewarding behaviour producing quantifiable outcomes.

Measuring performance according to the company's manufacturing strategy requires more than measuring tangible aspects and past performance. This is also reflected in Lebas and Euske's definition of performance: "performance is the sum of all processes that will lead managers to taking appropriate actions in the present that will lead to measured value tomorrow" [10, p.68]. Marr defines "strategic performance measurement" as:

The organizational approach to define, assess, implement, and continuously refine organizational strategy. It encompasses methodologies, frameworks and indicators that help organizations in the formulation of their strategy and 
enable employees to gain strategic insights which allow them to challenge strategic assumptions, refine strategic thinking, and inform strategic decision making and learning [3, p.4]

Lev [11] describes intangibles as non-physical claims to future benefits, and mentions a patent, a brand and a unique organizational structure as examples. The values of intangible resources are context specific [12]. They are attributed to an organization, supporting capabilities and contribute to the delivery of the company's value proposition [3]. Traditional, accounting based information systems are not able to provide adequate information about corporate intangible assets and their economic impact. One example is the innovation process since much of the economic value created in today's organisations stems from the process of creating new products (and services or processes) and the production and commercialization of these [12].

The intangible aspects normally have to be measured through qualitative methods, or proxies and indirect measures which often only capture a fraction of what we want to measure [13].

Kaplan and Norton [14] and their "Balanced Scorecard" is a well known approach for performance measurement. Lev's [11] "Value Chain Scoreboard" focusing on innovation is another example, but there are many approaches and methods that could guide us towards key measures, and enable us to work more structured on strategic performance measurement (see [15] and [1]).

\subsection{Measuring Agile and Lean Manufacturing Strategies}

Until 1980 the manufacturing strategies were oriented towards cost reduction through volume, and increasingly towards quality aspects [16]. This resulted in a stream of research on productivity (see [16], [17] and [18]). Authors, such as Bicheno [19] concentrated on contrasting different dimensions of productivity and total factor productivity was a fundamental measure [16].

One of Skinners [20] core arguments was that operations managers had to decide whether to compete on the basis of quality, time, cost, or flexibility, thus measurement of other aspects became more relevant. This was also in line with lean and flexible manufacturing principles that evolved during the 70's and 80's. Liker [21] describe major principles of lean manufacturing through the "4-P Model of the Toyota Way”. Womack, Jones and Roos [22] describe similar principles:

1. specify value in the eyes of the customer

2. identify the value stream and eliminate waste

3. make value flow at the pull of the customer

4. involve and empower employees

5. continuously improve in the pursuit of perfection

To measure how well we perform on a strategy based on these principles requires not only measuring those things that are quantifiable and backward looking such as product quality, SMED (Single Minute exchange of Dies9, Just-In-Time, and time to market. The more intangible aspects such as customer relations, knowledge and innovativeness, teamwork and improvement efforts also have to be measured. 


\section{A Case from the Automotive Industry}

Our case is a first tier supplier in the automotive industry where strategy documents refer to lean manufacturing. Empowering employees, continuous improvement in collaboration with customers and waste reduction are emphasized. This should also represent the basic elements of their performance measurement, thus containing a variety of measures to capture both tangible and intangible aspects.

Their performance measurement system is based on the automotive quality system IS0/TS 16949:2002 and their ERP system. The quality system is influenced by lean principles such as customer orientation and continuous improvement. The company states that they actively use their Key Performance Indicators (KPI) developed by "best practice teams", to follow up and support strategy and improvements.

Table 2. KPI's of a supplier in the automotive industry

\begin{tabular}{|c|c|c|c|}
\hline & KPI & Definition & Source \\
\hline 1 & Logistics & & \\
\hline 1.1 & Delivery perf. suppliers \% & Delivered quantity and date correct $=100 \%$ or else $0 \%$ & ERP \\
\hline 1.2 & Delivery perf. customers $\%$ & Delivered quantity and date correct $=100 \%$ or else $0 \%$ & ERP \\
\hline 1.3 & Delivery perf. inter company $\%$ & Delivered quantity and date correct $=100 \%$ or else $0 \%$ & ERP \\
\hline 1.4 & Stock raw material, days & Raw/Delivery scheduled & ERP \\
\hline 1.5 & Stock semi manufactured, days & W.I.P/Delivery scheduled & ERP \\
\hline 1.6 & Stock finished goods, days & Finished/Delivery scheduled & ERP \\
\hline 1.7 & Total stock, days & Raw+W.I.P+ Finished/Delivery scheduled & ERP \\
\hline 1.8 & Cost of extra ordinary freights & Total cost for all extra ordinary freights & ERP \\
\hline 2 & Manufacturing & & \\
\hline 2.1 & Quality administrative PPM & Ad..Claims/Sum of delivered parts & ERP \\
\hline 2.2 & Quality product PPM & Product claims/Sum of delivered parts & ERP \\
\hline 2.3 & Quality customer PPM & Total=Product+adm.claims/Sum of delivered parts & \\
\hline 2.4 & Quality inter company outbound PPM & Product claims/Sum of delivered parts & ERP \\
\hline 2.5 & Efficiency \% Direct labour & Outcome hours (manufacturing PID's)/Standard hours & Local/ERF \\
\hline 2.6 & Overall Equipment efficiency $\%$ & Availability*Perfprmance*Quality & Procedure \\
\hline 2.7 & Cost center gap & Sum of cost center gaps excl. productivity & ERP \\
\hline 3 & HSE (Health Security Environn & & \\
\hline 3.1 & $\mathrm{H}$-value Injuries/Mhr. & Number of injuries with absence/total hours & Local \\
\hline 3.2 & Absence short term \% & Absence paid by the company & Local \\
\hline 3.3 & Absence long term $\%$ & Absence mainly paid by government (Not company) & Local \\
\hline 3.4 & Absence unexcused $\%$ & Absence for other reasons paid by employee & Local \\
\hline 3.5 & Absence total \% & Total $=$ short term?long term+Not excused - monthly & Local \\
\hline 3.6 & El.energy consumption (Mwh) & Total electricity consumption & Local \\
\hline 3.7 & Water consumption $\left(\mathrm{m}^{3}\right)$ & Total water consumption & Local \\
\hline 3.8 & Oil consumption $\left(\mathrm{m}^{3)}\right.$ & Lubricants, diesel and fuel oil and gas for heating & Local \\
\hline 3.9 & $\mathrm{CO} 2$ Emission, fuel oil heating (tons) & Calculated on usage of oil & Local \\
\hline 3.10 & SO2 Emissions, fuel oil heating (tons) & Calculated on usage of oil & Local \\
\hline 3.11 & Special waste (tons) & Total special waste, not recycled & Local \\
\hline
\end{tabular}

The performance measurement system has several characteristics to make it a useful strategic tool:

- establish best practice for reporting KPI from operations

- distribute to all concerned through intranet

- data broken down on plant, team level and line/equipment

- reported on a regular basis, based on KPI specification

- accompanied by graphs showing trends over time

- mandatory in team reviews and management meetings 
The requirement of their most important customer $\left(\mathrm{OEM}^{1}\right)$, is the premise provider for the measurements where quality- and logistics requirement are emphasized. The majority of the indicators in Table 2 are reported monthly to the OEM. If the measures do not meet the requirements more frequent measurements, deeper investigation and analysis are normally required.

Does the performance measurement systems' focus on logistics, product quality, productivity, HSE and environmental impact cover the main issues of their lean manufacturing strategy?

The company may be accused of being backward looking and measuring what is easy to measure, while intangible aspects such as customer/supplier relations, teamwork, learning and innovativeness are not really measured. Product quality $\left(\mathrm{PPM}^{2}\right)$ and delivery performance to customers are possible indicators of customer relations, but hardly capture the intangible elements such as to which extent they really work together in problem solving, improvements, learning and innovations. The only measures for intangible aspects are within HSE and absence (3.1-3.5), where the measures could indicate working conditions. Interviews with managers showed that the measures that are emphasized and considered important are even fewer than what are reported in the measurement system. One of the senior managers stated that the important measures were: "EBIT ${ }^{3}$, net working capital, productivity, customer PPM, delivery precision and investments".

\section{How Could the Intangible Aspects of the Strategy Be Measured?}

Keeping our example from the automotive industry in mind there are basically two alternative ways of measuring the intangible aspects of the lean strategy; using traditional, objective, quantifiable indicators, or qualitative/subjective measures. A combination of these two would of course be possible. Theory suggests qualitative measures as appropriate performance measures if it is difficult to define objective performance targets or difficult to measure results [24][25]. The problem is their subjectivity and their descriptive nature making it difficult to compare measures in time, space and between respondents.

Indicators are often quantifiable, but less accurate and valid as measures. Qualitative measures are normally quite accurate, since we for example might ask stakeholders how well we fulfil their needs. An indicator of a shareholders satisfaction could be share value or dividend. Measures are far too often imposed on people and involving those people working in the particular field would normally generate good ideas of how to measure.

Defining relevant performance indicators will normally require a way to break down and make more detailed descriptions of the aspects we want to measure. This is illustrated in Fig.1 where the "pull principle $(3)^{4}$ ", and to some extent "waste reduction (2)", are detailed into a level where we might derive indicators [23].

\footnotetext{
${ }^{1}$ OEM= Original Equipment Manufacturer e.g VOLVO, GM and IVECO

${ }^{2} \mathrm{PPM}=$ Parts Per Million - used as a measure for parts that not having the required quality.

${ }^{3}$ EBIT $=$ Earnings Before Interest and Tax.

${ }^{4}$ Numbers relate to list of lean principles [23] on page 4 .
} 


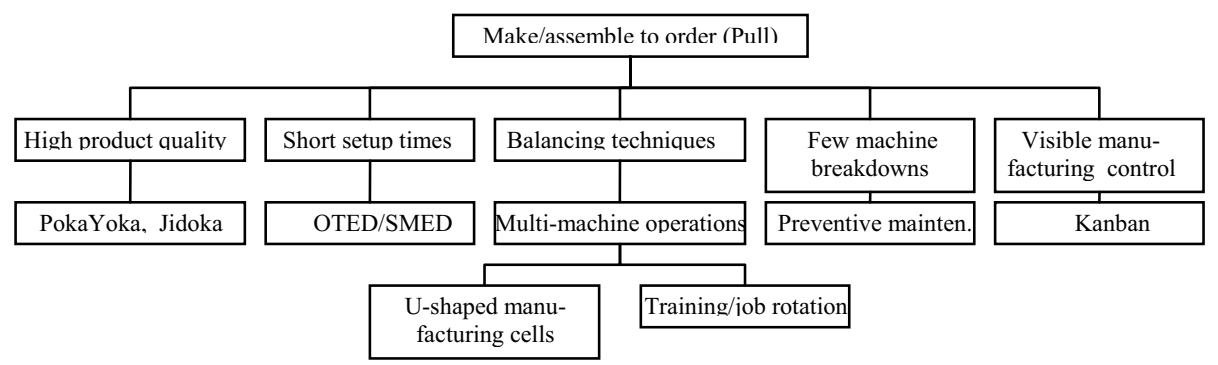

Fig. 1. Logic behind lean manufacturing, based on Skorstad [23]

Even though the measures we derive from Fig.1 are mainly quantitative of nature, there are also intangible aspects for example related to motivation for training, maintenance and Jidoka ${ }^{5}$ that are important to capture.

To which degree "employees are involved and empowered (4)" could bee measured by indicators such as tasks performed or decisions made by people in the different parts of the organization. The employees themselves have to feel that they have power and are involved in important activities. To capture this subjective data in-depth interviews and questionnaires could help us.

How well the company "continuously improve in the pursuit of perfection (5)" is measured through productivity (2.5 and 2.6 in table 2), quality (2.1-2.4) etc over time. But these measures do not necessarily measure the efforts put into improvements or innovations. Number of projects, cross functional team-meetings, improvement suggestions, patents applications could be indicators for improvement efforts. Especially indicators describing knowledge creation could be important for understanding our long term potential. Lev's [11] "Value Chain Scoreboard" proposes a detailed set of disclosures under three headings:

1. Discovery and learning: internal renewal, acquired capabilities and networking

2. Implementation: intellectual property, internet and technological feasibility

3. Commercialization: customers, performance (revenues) and growth prospects

To which extent the lean company in our example "specify value in the eyes of the customer (1)" is indicated by the quantitative measures in Table 2: delivery performance customers (1.2) and the quality measures (2.1-2.4). These measures of time and quality have been defined by the main customer, but are they useful as strategic indicators for describing our relations with customers or just to satisfy the reporting regime imposed by the OEMs? Qualitative measures, such as customer surveys and interviews, could be necessary to get the real picture.

\section{Conclusion}

Measuring performance according manufacturing strategies is essential. Customer orientation, flexibility, partnership, decentralization, continuous improvement,

\footnotetext{
${ }^{5}$ Jidoka (automatic halt of manufacturing if defects occur).
} 
knowledge and innovation, are some of the aspects that have got increased attention in lean manufacturing and other more recent paradigms. To measure how the companies perform they also have to capture intangible aspects, but might be difficult since we have to accept measures that are not accurate.

Indicators and qualitative measures might be difficult to derive. Qualitative measures could be accurate, but also resource demanding and difficult to implement as an integrated part of operations. Since intangible aspects often have to be measured through indicators we must be aware that they often only capture a fraction of what we want to measure, and have to be treated accordingly.

Adding intangible aspects to the performance measurement system increase the risk of having too many metrics. Metrics that no one knows why are being collected, with measures that are not measuring what they are supposed to measure or what really matters, just giving us an administrative burden.We believe that this process will be better off if strategies and performance measurement systems are developed with a broad involvement of employees and partners.

Through a case from the automotive industry we have illustrated how major aspects of lean strategies might be approached and measured. Even though the manufacturing strategy of the case company is defined as lean we see that the performance measurements cover traditional productivity aspects but also quality and delivery precision which is important in lean manufacturing. Even those there are some indicators related to the more intangible aspects, especially within HSE, there is difficult to find answers in the performance measurement system of important lean aspects such as: Do they collaborate well with customers and other stakeholders? Are the employees empowered and is there a culture for continuous improvement? How are the conditions for knowledge creation, innovation, learning and continual improvement?

Measurement directs behaviour. If a company is not able to measure the different facets of the manufacturing strategy there is a risk for pursuing, often unconsciously, mainly the principles and goals that are measured. If the intangible aspects of for example a lean strategy are not measured the issue could be raised to which extent the company really has such a strategy.

\section{References}

1. Busi, M.: An integrated Framework for Collaborative Enterprise Performance Management. Doctoral Thesis at NTNU: 48 (2005)

2. Behn, R.D.: Why Measure Performance? Different Purposes Require Different Measures. Public Administration Review 63(5), 586-606 (2003)

3. Marr, B.: Strategic performance management. In: Leveraging and measuring your intangible value drivers. Elsevier, Oxford (2006)

4. Tait, N.: Handling the sourcing decisions: Lowest Cost is not Always the Answer. Financial Times 13 (October 15, 1997)

5. Andersen, B., Aarseth, W., Henriksen, B.: Holistic performance management: an integrated framework. International Journal of Productivity and Performance Management 55(1), 61-78 (2006) 
6. Denzin, N., Lincoln, Y.: Introduction: Entering the field of Qualitative research. In: Denzin, N., Lincoln, Y. (eds.) Handbook of Qualitative Research, pp. 1-17. Sage Publications, London (1994)

7. Henriksen, B., Rolstadås, A.: Knowledge and manufacturing strategy - How different manufacturing paradigms have different requirements to knowledge. Examples from the automotive industry. International Journal of Production Research, iFirst, 1-18 (2009)

8. Hill, T.: Manufacturing strategy. Palgrave Macmillan, New York (2000)

9. Austin, R., Hoffer Gittell, J.: When it should not work but does: Anomalies of high performance. In: Neely, A. (ed.) Business Performance Measurement. Theory and Practice. Cambridge University Press, Cambridge (2002)

10. Lebas, M., Euske, K.: A conceptual and operational delineation of performance. In: Neely, A. (ed.) Business Performance Measurement: Theory and Practice, pp. 65-79. Cambridge University Press, Cambridge (2002)

11. Lev, B.: Intangibles: management, measurement and reporting. Brookings Institution Press, Washington (2001)

12. Lev, B., Daum, J.H.: The dominance of intangible assets: consequences for enterprise management and corporate reporting. Measuring Business Excellence 8(1), 6-17 (2004)

13. Blair, M., Wallman, S.: Unseen Wealth. Brookings Institution, Washington (2001)

14. Kaplan, R.S., Norton, D.P.: The Balanced Scorecard. Harvard Business School Press, Boston (1996)

15. Bourne, M., Neely, A., Mills, J., Platts, K.: Implementing performance measurement systems: a literature review. International Journal of Business Performance Management 5(1), $1-24(2003)$

16. Neely, A., Austin, R.: The operations perspective. In: Neely (ed.) Business Performance Measurement. Theory and Practice, pp. 41-50. Cambridge University Press, Cambridge (2002)

17. Kendrick, J.W.: Improving Company Productivity. In: Handbook with Case Studies. John Hopkins University Press, Baltimore (1984)

18. Sink, D.S.: Productivity Measurement - Planning, Measurement and Evaluation, Control and Improvement. John Wiley and Sons, Chichester (1985)

19. Bicheno, J.R.: Cause and Effect of JIT: A Pocket Guide. PICSIE Books, Buckingham (1989)

20. Skinner, W.: Manufacturing - missing link in corporate strategy. Harvard Business Review 50(3), 136-145 (1969)

21. Liker, J.: The Toyota Way. In: 14 Management Principles from the World's Greatest Manufacturer. McGraw Hill, New York (2003)

22. Womack, J.P., Jones, D.T., Roos, D.: The Machine That Changed the World. HarperCollins, New York (1991)

23. Skorstad, E.J.: Produksjonsformer i det tyvende århundre. Organisering, arbeidsvilkår og produktivitet. In: Production in the 20th Century. Organization, Work Conditions and Productivity. AD Notam Gyldendal, Oslo (1999)

24. Bushman, R., Indjejikian, R., Smith, A.: CEO Compensation: The Role of Individual Performance Evaluation. Journal of Accounting and Economics 21, 161-193 (1996) 